\title{
Management and Clinical Outcomes of Iatrogenic Injury Secondary to Endoscopic Retrograde Cholangiopancreatography
}

\author{
Endoskopik Retrograd Kolanjiopankreatografi Sonrasındaki işleme Bağlı \\ Yaralanmaların Tedavisi ve Klinik Sonuçlarımız
}

\author{
(D) Ramazan Sarı, (1) Hakan Yabanoğlu, (D) Murat Kuş, (D Illker Murat Arer
}

Bașkent University Adana Dr. Turgut Noyan Application and Research Center, Department of General Surgery, Adana, Turkey

\begin{abstract}
Introduction: Perforation secondary to endoscopic retrograde cholangiopancreatography (ERCP) is a rare complication but a problematic one because of associated morbidity and mortality. In our study, we aimed to define correct timing for surgery, to analyze and present our results on suitable methods that can be used in the surgical management of perforation secondary to ERCP done for various indications.

Methods: The data were collected from 19 patients who underwent surgery for perforation secondary to ERCP. We retrospectively analyzed clinical and demographic characteristics with the treatment outcomes of these patients.

Results: The mean age of the patients was 57 years (range: 1692). The ERCP procedure was for therapeutic purposes in all the patients. Perforation mostly occurred during sphincterectomy, as was seen in 12 patients (63\%). The patients underwent surgical intervention at a mean of 42.5 hours (range: $3-192$ ) after perforation. Postoperative mortality occurred in seven patients (36.8\%). The mean hospitalization period was 16.5 days (range: 11-49).

Conclusion: Duodenal perforation is an ERCP-related complication that carries high mortality and morbidity risks, even in experienced tertiary centers. When perforation is suspected, these patients should immediately be referred to experienced centers/units for further management. Careful scrutiny of clinical and radiological findings is critical in choosing the appropriate surgical intervention.
\end{abstract}

Keywords: Endoscopic retrograde cholangiopancreatography, perforation, surgical treatment

\section{öZ}

Amaç: Endoskopik retrograd kolanjiyo pankreatografi (ERCP) sonrası perforasyon nadir görülen bir komplikasyondur; ancak morbidite ve mortalitesi nedeniyle yönetimi problemlidir. Çalışmamızda, ameliyat için doğru zamanlamayı tanımlamayı, çeşitli endikasyonlar için yapılan ERCP sonrası perforasyonun cerrahi tedavisinde kullanılabilecek uygun yöntemler üzerine sonuçları analiz etmeyi ve sunmayı amaçladık.

Yöntemler: ERCP'ye bağıı perforasyon nedeniyle ameliyat edilen 19 hastanın verileri toplandı. Bu hastaların tedavi sonuçları ile klinik ve demografik özellikleri retrospektif olarak incelendi.

Bulgular: Hastaların yaş ortalaması 57 (16-92) idi. ERCP prosedürü tüm hastalarda tedavi amaçlı uygulanmıștı. Hastaların 12'sinde (\%63) perforasyon sfinkterektomi sırasında meydana geldi. Hastalara perforasyon sonrası ortalama 42.5 (3-192) saat sonra cerrahi girişim uygulandı. Postoperatif 7 $(\% 36,8)$ hastada mortalite gözlendi. Ortalama hastanede kalıs süresi 16,5 gün (11-49) idi.

Sonuç: Duodenal perforasyon, deneyimli merkezlerde bile yüksek mortalite ve morbidite riskleri taşıyan ERCP ilişkili bir komplikasyondur. Perforasyondan şüphelenildiğinde, bu hastalar derhal ileri tedavi için deneyimli merkezlere/birimlere yönlendirilmelidir. Uygun cerrahi müdahalenin seçiminde klinik ve radyolojik bulguların dikkatli bir şekilde incelenmesi çok önemlidir.

Anahtar Kelimeler: Endoskopik retrograd kolanjiyopankreatografi, perforasyon, cerrahi tedavi

\section{Introduction}

Endoscopic retrograde cholangiopancreatography (ERCP) has been used in managing diseases of the biliary system and pancreas since its introduction in 1974 (1). With an increased scope of use, the reported complication rate ranges from 5-10\% and includes pancreatitis, hemorrhage, and perforation (2). Perforation secondary to ERCP is a rare complication but a problematic one because of associated morbidity and mortality. Early suspicion and directed diagnostic imaging are vital for proper diagnosis and effective clinical management. Non-surgical interventions like endoscopic repair and stenting are options if the injury
Address for Correspondence/Yazıșma Adresi: Ramazan Sarı MD, Bașkent University Adana Dr. Turgut Noyan

Application and Research Center, Department of General Surgery, Adana, Turkey

Phone: +90 5056294662 E-mail: sariramazan71@gmail.com ORCID ID: orcid.org/0000-0003-3492-9953

Cite this article as/Atıf: Sarı R, Yabanoğlu H, Kuș M, Arer IM. Management and Clinical Outcomes of Iatrogenic Injury Secondary to Endoscopic Retrograde Cholangiopancreatography. İstanbul Med J 2020; 21(1): 28-32.
Received/Geliș Tarihi: 18.06.2019 Accepted/Kabul Tarihi: 11.12.2019

(c) Copyright 2020 by the Istanbul Training and Research Hospital/istanbul Medical Journal published by Galenos Publishing House.

(C) Telif Hakkı 2020 İstanbul Ĕğitim ve Araștırma Hastanesi/Istanbul Tıp Dergisi, Galenos Yayınevi tarafından basılmıștır. 
is detected during the procedure. In some cases, monitoring the patient without any intervention is sufficient. However, based on the type of injury and its clinical outcomes, surgery is inevitable in some cases (3). The type of surgical intervention varies considerably depending on the location of the perforation, its size, and time from perforation to initiation of the treatment. There is no consensus on a uniform procedure of choice.

In this study, we aimed to define the correct timing for surgery, to analyze and present results on suitable methods that can be used in the surgical management of perforation secondary to ERCP.

\section{Methods}

In this study, we retrospectively analyzed the files of 19 patients who underwent surgery for perforation secondary to ERCP done between January 1999 and January 2019. This study was approved by the Başkent University Medical and Health Sciences Research Board Ethical Committee (decision no: KA19/84). Informed consent was obtained from all patients before ERCP and before surgical intervention for ERCPrelated perforation. The demographic and clinical characteristics of the patients, ERCP indications, location and type of perforation, diagnostic methods, the clinical course of the condition, timing for the operation, the surgical procedure applied, hospitalization period, postoperative complications, and treatment outcomes were analyzed. Based on the surgery notes and computerized tomography (CT) reports, it was noted that Stapfer classification was used to grade the ERCP perforations (Table 1) (4).

The vital signs and the physical examination of the patients, leukocytosis, the presence of peritoneal free air, or fluid on CT and/or abdominal X-ray were also analyzed. The patients were categorized into two distinct groups: The early surgical group included the patients in whom perforation was diagnosed during the procedure and surgery was performed within 6 hours, whereas the rest of the patients were classified as the late surgical group.

\section{Statistical Analysis}

The SPSS 17.0 program was used to statistically analyze the demographic and clinical data of patients as well as to interpret the outcomes.

\section{Results}

Eleven (58\%) of the 19 patients were female, while 8(42\%) were male, with a mean age of 57 years (range: 16-92). One patient was under 18 years of age and was operated on by a pediatric surgeon. Eight of the patients had severe comorbidities such as hypertension, diabetes, and coronary artery disease. One patient had cardiopulmonary arrest during the ERCP procedure and was taken to theatre for operation after resuscitation and stabilization of vitals. Thirteen patients (68\%) underwent ERCP procedure at our center, whereas the remaining six patients (32\%) were referred to our center for further management after ERCP-related injury at other centers. The ERCP procedure was for therapeutic purposes in all the patients, including 14 (74\%) for choledocholithiasis and five (26\%) for biliary stent placement for various reasons. Perforation mostly occurred during sphincterectomy, as was seen in 12 patients (63\%). Perforation occurred in three patients (16\%) during stent placement and in two patients $(10 \%)$ during manipulation of the endoscope. There was no data about the stage at which the perforation occurred in two referred patients (10\%). In six patients, perforation was diagnosed during the ERCP procedure and they underwent surgery within six hours. While in the remaining 13 patients, perforation was diagnosed later during the post-ERCP clinical follow-up, hence they underwent surgery late. In these 13 patients (68\%), there was abdominal tenderness, fever, and tachycardia. There was subcutaneous emphysema in five patients (26\%). There was leukocytosis in 11 patients (58\%) at diagnosis. These 11 patients had retroperitoneal or intraperitoneal free air on CT imaging. There were intraperitoneal and retroperitoneal abscess and free fluid in the delayed cases. The patients underwent surgical intervention at a mean of 42.5 hours (range: 3-192) after perforation. According to Stapfer classification, the most common perforation was type 1 that was seen in ten patients (52.6\%), while type 2 was seen in five patients (26.3\%), and type 3 was seen in one patient (5.3\%). Type 4 perforation was seen in three patients (15.8\%) (Table 2). In six of the ten patients with type 1 perforation, the site was localized and repaired with primary sutures. In three patients who presented late, primary repair was not plausible due to inflammation and tissue fragility. In one case of advanced cholangiocelullar carcinoma, primary duodenostomy was preferred, as the primary repair was not adequate. One patient with periampullary tumor underwent pancreaticoduodenectomy. All clinical data, surgical procedures utilized, and postoperative results are as shown in detail in Table 3.

Postoperative mortality occurred in seven patients (36.8\%). Five patients (26.3\%) died due to sepsis-related multiorgan failure on Days 2., 3., 4., 5., and 8., whereas one patient had cardiac arrest due to myocardial infarction (MI) during ERCP procedure and died on Day 3 for cardiacrelated reasons. One patient with preexisting hepatic insufficiency had decompensated failure and died on postoperative Day 10 . The remaining 12 patients were eventually discharged from the hospital on mean postoperative Day 16.5. However, during perioperative management, two patients developed an intraabdominal abscess, one patient had sepsis, one patient had cardiac arrest during surgery, one patient had

\begin{tabular}{|c|c|}
\hline Perforation type & Localization \\
\hline Type 1 & $\begin{array}{l}\text { Lateral or medial duodenal wall, away from the } \\
\text { ampulla }\end{array}$ \\
\hline Type 2 & Periampullary vateri injury \\
\hline Type 3 & Biliary tree or pancreatic duct injury \\
\hline Type 4 & Only free air in the retroperitoneal space \\
\hline
\end{tabular}

Table 2. Patient distribution according to type of injury

\begin{tabular}{|l|c|l|}
\hline Type & Patient number $(\mathbf{n}=\mathbf{1 9})$ & Ratio (\%) \\
\hline Type 1 & 10 & 52.6 \\
\hline Type 2 & 5 & 26.3 \\
\hline Type 3 & 1 & 5.3 \\
\hline Type 4 & 3 & 15.8 \\
\hline
\end{tabular}


hemorrhage at the gastroenterostomy site, and one patient developed surgical site infection (Table 3).

\section{Discussion}

ERCP-related complications are very low when the procedure is done by experienced endoscopists. There is a reported complication rate of 4-16\% $(5,6)$. Duodenal perforation is the most common cause of mortality and morbidity among these complications (7). Perforation is more common in ERCP done for therapeutic reasons with a mean occurrence rate of $1 \%$ and related mortality of around $50 \%$ in cases that require surgical intervention $(7,8)$. In our study, all patients underwent therapeutic ERCP with a mortality rate of $36 \%$ after surgical intervention.

Based on etiology and perforation, drainage, or conservative medical treatment options are other management options (9). However, in some cases, based on worsening clinical condition or change in imaging findings, surgical intervention may be necessary. In our study, perforation was not detected during the procedure in 13 patients (68.4\%).
The decision for surgery was made during in-patient follow up due to worsening clinical conditions of these patients. The most important step in the management of ERCP related perforations is determining which patients require surgery and the correct timing of the intervention (10). Besides the detection of perforation during the procedure, patient's clinical condition and CT findings play a vital role in deciding surgical intervention. In our study, patients had three out of four clinical signs, such as fever, tachycardia, leukocytosis, and abdominal tenderness, as described by Knudson et al. (11) for ERCP-related perforation.

A study highlighted that physical examination was more valuable than radiological findings as intraperitoneal free air can be managed conservatively just as in peptic ulcer perforation (12). CT findings for perforation may include duodenal wall thickening, intramural air, retroperitoneal adipose tissue contamination or collection, extravasation of contrast, and intraperitoneal, retroperitoneal or subcutaneous free air (13). In our study, perforation was detected early in six patients, and they underwent immediate surgical intervention. In these patients who

\section{Table 3. Demographic and clinical characteristics of patients}

\begin{tabular}{|c|c|c|c|c|c|c|c|c|c|}
\hline & G/A & Comorbidity & Diagnosis & Reason of Injury & Type & Surgical therapy & Complication & Day & Result \\
\hline 1 & $\mathrm{M} / 79$ & $C A D+D M$ & Choledocholithiasis & Cannulation & 2 & $\mathrm{CE}+\mathrm{T}-\mathrm{Tube}+\mathrm{GE}$ & Sepsis & 20 & Discharged \\
\hline 2 & $\mathrm{~F} / 72$ & HT & Choledocholithiasis & Cannulation & 1 & $\mathrm{CE}+\mathrm{T}-\mathrm{Tube}+\mathrm{GE}$ & Sepsis & 5 & Exitus \\
\hline 3 & $\mathrm{M} / 75$ & COPD & Choledocholithiasis & Endoscope & 1 & $\mathrm{PS}+\mathrm{CE}+\mathrm{T}-\mathrm{Tube}+\mathrm{C}$ & None & 11 & Discharged \\
\hline 4 & $\mathrm{~F} / 92$ & HT & Choledocholithiasis & Cannulation & 1 & $\mathrm{PS}+\mathrm{CE}+\mathrm{T}-\mathrm{Tube}+\mathrm{C}$ & Wound inf. & 30 & Discharged \\
\hline 5 & $F / 36$ & None & Chronic pancreatitis & Stenting & 1 & $\mathrm{PS}+\mathrm{GE}$ & Sepsis & 3 & Exitus \\
\hline 6 & $\mathrm{M} / 61$ & None & Pancreatic cancer & Stenting & 2 & Whipple procedure & IA abscess & 30 & Discharged \\
\hline 7 & $\mathrm{~K} / 69$ & None & Choledocholithiasis & Cannulation & 2 & $\mathrm{PS}+\mathrm{CE}+\mathrm{T}-\mathrm{Tube}+\mathrm{C}$ & None & 22 & Discharged \\
\hline 8 & $F / 61$ & None & Bile Fistulae & Stenting & 3 & $\mathrm{CE}+\mathrm{T}-\mathrm{Tube}+\mathrm{GE}$ & Sepsis & 2 & Exitus \\
\hline 9 & $\mathrm{M} / 78$ & CAD & Biliary tree cancer & Endoscope & 1 & $\mathrm{DO}+\mathrm{GE}$ & $\mathrm{MI}$ & 3 & Exitus \\
\hline 10 & $\mathrm{M} / 61$ & None & Choledocholithiasis & Cannulation & 4 & $\mathrm{CE}+\mathrm{T}-\mathrm{Tube}+\mathrm{GE}$ & Sepsis & 8 & Exitus \\
\hline 11 & $\mathrm{~F} / 51$ & None & Choledocholithiasis & Cannulation & 1 & $\mathrm{PS}+\mathrm{CE}+\mathrm{T}-\mathrm{Tube}+\mathrm{C}$ & None & 18 & Discharged \\
\hline 12 & $F / 16$ & None & Choledocholithiasis & Cannulation & 2 & $\mathrm{CE}+\mathrm{T}-\mathrm{Tube}+\mathrm{GE}+\mathrm{C}$ & None & 21 & Discharged \\
\hline 13 & $\mathrm{M} / 46$ & $\mathrm{HT}+\mathrm{HBV}$ & Choledocholithiasis & Cannulation & 1 & $\mathrm{PS}+\mathrm{CE}+\mathrm{T}-\mathrm{Tube}+\mathrm{C}+\mathrm{GE}$ & MOF & 10 & Exitus \\
\hline 14 & $\mathrm{~F} / 23$ & None & Choledocholithiasis & Cannulation & 1 & $\mathrm{CE}+\mathrm{T}-\mathrm{Tube}+\mathrm{GE}$ & None & 19 & Discharged \\
\hline 15 & $\mathrm{M} / 56$ & None & Choledocholithiasis & Cannulation & 1 & $\mathrm{CE}+\mathrm{T}-\mathrm{Tube}+\mathrm{GE}$ & IA abscess & 13 & Discharged \\
\hline 16 & $\mathrm{~F} / 81$ & HT & Choledocholithiasis & Cannulation & 1 & $\mathrm{CE}+\mathrm{T}-\mathrm{Tube}+\mathrm{C}+\mathrm{GE}+\mathrm{BTV}$ & Sepsis & 4 & Exitus \\
\hline 17 & $\mathrm{M} / 29$ & None & Choledocholithiasis & Unknown & 4 & $\mathrm{CE}+\mathrm{T}-\mathrm{Tube}+\mathrm{GE}$ & HIE & 32 & Discharged \\
\hline 18 & $F / 42$ & None & Choledocholithiasis & Cannulation & 2 & $\mathrm{CE}+\mathrm{T}-\mathrm{Tube}+\mathrm{GE}+\mathrm{C}$ & Bleeding & 13 & Discharged \\
\hline 19 & $F / 48$ & DM & Mirizzi syndrome & Unknown & 4 & $\mathrm{CE}+\mathrm{T}-\mathrm{Tube}+\mathrm{GE}+\mathrm{C}$ & None & 49 & Discharged \\
\hline
\end{tabular}

Table 4. Mortality and complication rate

\begin{tabular}{|l|l|}
\hline Mortality & Early surgery $(<\mathbf{6}$ hours), $\mathbf{n}=\mathbf{6}$ patient \\
\hline 1 patient $(16.6 \%)$ \\
\hline Complications & $\begin{array}{l}1 \text { patient }(16.6 \%) \\
\text { Wound infection }\end{array}$ \\
\hline
\end{tabular}

GE: gastroenterostomy, HIE: hypoxic-ischemic encephalopathy, IA: intraabdominal

\author{
Late surgery ( $>6$ hours), $\mathrm{n}=13$ patients \\ 6 patients (46.1\%) \\ 5 patients (38.4\%) \\ IA abscess: 2 patients \\ Sepsis: 1 patient \\ Bleeding from GE: 1 patient \\ HIE: 1 patient
}


received surgical intervention within six hours, mortality rate was $16.6 \%$, as only one patient died. This patient had cholangiocellular carcinoma and died due to MI during treatment. Infection was observed in just one patient. Eleven of the 13 delayed surgery patients required a CT to fully diagnose the perforation, whereas, in two patients, clinical examination was sufficient to decide to operate. Mortality occurred in six patients (46.1\%) in this group at a rate observed to be comparably higher than the early group (38.4\%). The mean hospitalization period was 17.5 days for the early group but 16 days for the late group. There was no statistically significant difference noted in the hospitalization periods. The mortality and complication rates of the individual groups are as shared in Table 4.

In line with published data, our study underscores the importance of early diagnosis and timely intervention. As much as the choice of surgical procedure is dependent on size or type of perforation and extent of inflammation, the main aim of the procedure should be to close the defect and divert gastric content away from the duodenum. Pylorus should be excluded from gastrojejunostomy diversion to inhibit the activation of pancreatic enzymes (14). External drainage of the bile, where possible, will also hasten to heal. In our cases, the patients received definitive intervention for the underlying pathology that necessitated ERCP by choledochotomy and gallstone extraction followed by T-tube placement. External drainage of bile was therefore provided by T-tube. In delayed cases with extensive intraabdominal infection and cases of periampullary malignancy, pyloric exclusion, together with duodenostomy and/or gastrojejunostomy, was carried out. One patient with resectable periampullary tumor underwent a Whipple procedure.

Although postoperative mortality due to ERCP-related perforations varies depending on the patient's age, comorbidities, and timing of surgery, this rate is reported as $9-30 \%(15,16)$. Mortality is higher in elderly patients and cases of delayed surgical intervention. In our study, mortality was found to be $36.8 \%$, which is higher than reported rates. This can be attributed to delayed intervention in the three referred cases and advanced age together with comorbidities in the others. Six patients had no postoperative complications. Six patients with complications such as surgical site infections, intraabdominal abscess, and sepsis responded well to medical therapy. These patients were discharged from the hospital on postoperative Day 23 on average. There is no consensus on the surgical procedure of choice for patients with ERCP related perforations. Perforation site, the timing of intervention, and the presence of intraabdominal infection should be considered in decision-making. All studies published on this topic are retrospective in nature and include a limited set of patients. Our study is no exception to this limitation as it is also retrospective and contains a limited number of patients.

Because early diagnosis and intervention reduce mortality and morbidity, patients should be closely monitored after the ERCP procedure. More importantly, difficult ERCP procedure cases, patients with malignancyrelated indications for the procedure, and those with suspect clinical course after the ERCP should be monitored for perforation.

\section{Conclusion}

In summary, duodenal perforation is an ERCP-related complication that carries high mortality and morbidity risks, even in experienced tertiary centers. Careful scrutiny of clinical and radiological findings is very important in choosing the appropriate surgical intervention.

Ethics Committee Approval: This study was approved by the Başkent University Medical and Health Sciences Research Ethical Committee (decision no: KA19/84).

Informed Consent: Informed consent was obtained from all patients.

Peer-review: Externally peer-reviewed.

Author Contributions: Surgical and Medical Practices - H.Y., I.M.A.; Concept - R.S.; Design - H.Y.; Data Collection and/or Processing - M.K.; Analysis and/or Interpretation - R.S.; Literature Search - I.M.A.; Writing Manuscript - R.S.

Conflict of Interest: No conflict of interest was declared by the authors

Financial Disclosure: The authors declared that this study received no financial support.

\section{References}

1. Joyce AM, Heiss FW. Endoscopic evaluation and therapies of biliary disorders. Surg Clin N Am 2008; 88: 1221-40.

2. Freeman ML. Complications of endoscopic retrograde cholangiopancreatography: Avoidance and management. Gastrointest Endosc Clin N Am 2012; 22: 567-86.

3. Andriulli A, Loperfido S, Napolitano G, Niro G, Valvano MR, Spirito F, et al. Incidence rates of post-ERCP complications: a systematic survey of prospective studies. Am J Gastroenterol 2007; 102: 1781-8.

4. Stapfer M, Selby RR, Stain SC, Katkhouda N, Parekh D, Jabbour N, et al. Management of duodenal perforation after endoscopicretrograde cholangiopancreatography and sphincterotomy. Ann Surg 2000; 232: 191-8.

5. Kapral C, Duller C, Wewalka F, Kerstan E, Vogel W, Schreiber F. Case volume and outcome of endoscopic retrograde cholangiopancreatography: results of a nation wide Austrian bench-marking project. Endoscopy 2008; 40: 625-30.

6. Williams EJ, Taylor S, Fairclough P, Hamlyn A, Logan RF, Martin D, et al. Are we meeting the standards set for endoscopy? Results of a large scale prospective survey of endoscopic retrograde cholangio-pancreatograph practice. Gut 2007; 56: 821-9.

7. ChoKB. Themanagementofendoscopicretrogradecholangiopancreatographyrelated duodenalperforation. Clin Endosc 2014; 47: 341-5.

8. Krishna RP, Singh RK, Behari A, Kumar A, Saxena R, KapoorVK. Post-endoscopic retrograde cholangiopancreatography perforation managed by surgery or percutaneous drainage. Surg Today 2011; 41: 660-6.

9. Rabie ME, Mir NH, Al Skaini MS, El Hakeem I, Hadad A, Ageely H, et al. Operative and non-operative management of endoscopic retrograde cholangiopancreatography associated duodenal injuries. Ann R Coll Surg Engl 2013; 95: 285-90.

10. Machado NO. Management of duodenalperforation post-endoscopic retrograde cholangiopancreatography. When and whom to operate and what factors determine the outcome? A review article. JOP 2012; 13: 18-25.

11. Knudson K, Raeburn CD, McIntyre RC Jr, Shah RJ, Chen YK, Brown WR, et al. Management of duodenal and pancreaticobiliary perforations associated with periampullary endoscopic procedures. Am J Surg 2008; 196: 975-81.

12. Dubecz A, Ottmann J, Schweigert M, Stadlhuber RJ, Feith M, Wiessner V, et al. Management of ERCP-related small bowel perforations: the pivotal role of physical investigation. Can J Surg 2012; 55: 99-104. 
13. Pannu HK, Fishman EK. Complications of endoscopic retrograde cholangiopancreatography: spectrum of abnormalities demonstrated with CT. Radiographics 2001; 21: 1441-53.

14. Wu HM, Dixon E, May GR, Sutherland FR. Management of perforation after endoscopic retrograde cholangiopancreatography (ERCP): A population-based review. HPB (Oxford) 2006; 8: 393-9.
15. Miller R, Zbar A, Klein Y, Buyeviz V, Melzer E, Mosenkis BN, et al. Perforations following endoscopic retrograde cholangiopancreatography: a single institution experience and surgical recommendations. Am J Surg 2013; 206: 180-6.

16. Jin YJ, Jeong S, Kim JH, Hwang JC, Yoo BM, Moon JH, et al. Clinical course and proposed treatment strategy for ERCP-related duodenal perforation: a multi center analysis. Endoscopy 2013; 45: 806-12. 